\title{
Grazing Distribution and Diet Quality of Angus, Brangus, and Brahman Cows in the Chihuahuan Desert
}

\author{
Morgan L. Russell, ${ }^{1}$ Derek W. Bailey, ${ }^{2}$ Milt G. Thomas, ${ }^{2}$ and Barbara K. Witmore ${ }^{1}$ \\ Authors are ${ }^{1}$ Former Graduate Research Assistant and ${ }^{2}$ Professor, Animal and Range Sciences Department, New Mexico State University, \\ Las Cruces, NM 88003, USA.
}

\begin{abstract}
Grazing distribution can be improved by using adapted cattle breeds that travel to distant areas of extensive pastures. A 2-yr study was conducted to evaluate grazing distribution and diet quality of Angus, Brangus, and Brahman cows (seven cows per breed group) in the Chihuahuan Desert during three seasons (winter, early summer, and late summer) using three pastures. Two GPS collars were randomly assigned to each breed group and cow positions were logged every $10 \mathrm{~min}$ for 10- to 14-d periods in each pasture ( 3 periods $\cdot$ season $^{-1}$ ). In 2008 , breed groups were evaluated in separate pastures and data were analyzed as a $3 \times 3$ Latin square design. In 2009, all breed groups were evaluated at the same time in the same pastures. Fecal samples were collected in 2008 and analyzed using near infrared spectroscopy (NIRS) to estimate diet quality. If positions recorded when cows were resting were excluded, Brahman cows traveled greater distances per day than Angus cows throughout the study and greater $(P \leq 0.10)$ than Brangus cows in all but one season during 2009. No differences in average distance to water were detected $(P>0.10)$ among breed groups. During early summer in 2008 and early and late summer in 2009, Angus cows maintained a more linear grazing path $(P \leq 0.10)$ than Brangus or Brahman cows. Brahman cows displayed more sinuous grazing paths $(P \leq 0.10)$ than other breeds during early and late summer seasons in 2009. In 2008 , no differences in crude protein content of diets were detected $(P>0.10)$ among breed groups during all seasons. Spatial movement patterns of Brahman cows appeared to differ from Angus and Brangus cows; however, there was no evidence to suggest that there was any advantage in use of areas far from water by any breed group.
\end{abstract}

\begin{abstract}
Resumen
La distribución del pastoreo puede ser mejorada usando razas de ganado que se adapten a caminar largas distancias en potreros grandes. Se realizó un estudio de dos años para evaluar la distribución del pastoreo y calidad de la dieta de vacas Angus, Brangus, y Brahman (siete vacas por grupo racial) en el Desierto Chihuahuense durante tres temporadas (invierno, inicio, y finales de verano) usando tres potreros. Dos collares con GPS fueron asignados aleatoriamente a cada grupo racial y la posición de las vacas fue anotada cada 10 minutos por periodos de 10 a 14 días en cada potrero (tres periodos por temporada). En 2008, los grupos raciales fueron evaluados en porteros separados y los datos fueron analizados en un diseño de cuadro latino de $3 \times 3$. En 2009, todos los grupos raciales fueron evaluados al mismo tiempo en los mismos potreros. En 2008 se recolectaron muestras fecales y se analizaron usando espectroscopia infrarroja (NIRS) para estimar la calidad de la dieta. Sí se excluye el tiempo registrado de cuando las vacas estuvieron descansando, las vacas Brahman recorrieron mayores distancias por día que las vacas Angus a través del estudio y mayor $(P \leq 0.10)$ que las vacas Brangus en todos pero una temporada durante el 2009. No se encontró diferencia $(P>0.10)$ en distancia a el agua en promedio entre los grupos raciales. Durante el inicio del verano de 2008 e inicio y final del verano de 2009 las vacas Angus mantuvieron un patrón de pastoreo más lineal $(P \leq 0.10)$ que las vacas Brangus y Brahman. Las vacas Brahman mostraron un patrón mas sinuoso de pastoreo $(P \leq 0.10)$ que las otras razas durante el inicio y final del verano en 2009. En 2008 no se encontraron diferencias con relación al contenido de proteína cruda en las dietas $(P>0.10)$ entre los grupos raciales en todas las temporadas. El movimiento espacial de las vacas Brahmas parece diferir de las vacas Angus y Brangus; sin embargo, no hubo evidencia que sugiera de alguna ventaja en el uso de áreas distantes del agua para ningún grupo racial.
\end{abstract}

Key Words: breed, cattle behavior, fecal NIRS, GPS telemetry, grazing pathway, tortuosity

\section{INTRODUCTION}

Research was funded by the New Mexico State University Agricultural Experiment Station, Project 110000.

Correspondence: Derek W. Bailey, Dept of Animal and Range Sciences, New Mexico State University, P0 Box 30003, MSC 3-I, Las Cruces, NM 88003, USA. Email: dwbailey@nmsu.edu

Current address: Milt G. Thomas, Dept of Animal Sciences, Colorado State University, Fort Collins, C0 80523, USA

Manuscript received 4 March 2011; manuscript accepted 18 February 2012.
A key component of sustainable grazing management is the distribution of livestock (Walker 1995; Bailey 2004). By understanding interactions and relationships between abiotic and biotic factors and forage preferences, livestock distribution can be manipulated (Bailey et al. 1996). Strategic placement of shade (McIlvain and Shoop 1971), nitrogen fertilizer (Hooper et al. 1969), salt (Ganskopp 2001), fire (Vermeire et al. 2004), and supplemental feeds (Bailey and Welling 1999) have been 
used to attract cattle to areas that receive little grazing. Fencing and installation of new water developments can be effective for modifying distribution (Valentine 1947; Holechek 1988); however, these methods might not always be feasible or economical (Workman and Hooper 1968). In extensive rangeland pastures in the Chihuahuan Desert, fencing and water developments can represent too large a capital investment with little return due to low and variable forage production (Holechek et al. 1999).

Selection of livestock that use greater distances from water and steep terrain can facilitate improved distribution of livestock use in rangeland pastures (Bailey et al. 2001; VanWagoner et al. 2006). Herbel and Nelson (1966) reported Santa Gertrudis cows (three-eights Brahman and five-eights Shorthorn) walked greater distances per day $(12.5 \mathrm{~km})$ than Hereford cows $(7.8 \mathrm{~km})$ in extensive pastures of the Chihuahuan Desert. Correspondingly, the authors surmised that Santa Gertrudis grazed farther from water than Herefords. Hessle et al. (2008) reported Väneko heifers, a Swedish breed, had higher activity levels than Charolais heifers, which also suggests that some breeds might be more willing travel to distant areas from water than other breeds. VanWagoner et al. (2006) reported the cows sired by Piedmontese bulls used areas farther from water than Angus-sired cows in Montana foothill rangeland. Use of breeds that are more willing to travel far from water and use more rugged terrain potentially might reduce overgrazing of gentle slopes near water when compared to breeds that avoid steep slopes and are unwilling to walk long distances from water.

Variation in diet quality among breeds also might be related to diverse foraging patterns and overall grazing distribution. Mature Brangus cows (three-eights Brahman and five-eights Angus) tended to consume more mesa dropseed (Sporobolus flexuosus [Thurb. ex. Vasey] Rydb.) than Hereford or Angus cows in the Chihuahuan Desert (Winder et al. 1996). This difference in diet quality might be a result of the Brahman influence in Brangus cows that allowed them to locate and consume higher quality grasses more easily than Herefords or Angus cattle (Herbel and Nelson 1966).

Winder et al. (1992) analyzed heterotic effects on annual cow productivity for Hereford and Brangus cows and reciprocal crossbred cows under semidesert conditions. The authors reported an adaptive advantage for cows with Brangus sires and (or) dams resulting from expressed high levels of maternal heterosis. Crossing breeds of diverse genetic backgrounds results in heterosis, which can give a sizable genetic advantage to crossbred cattle such as Brangus cattle in foragelimited desert environments (Franke 1980; Winder et al. 1992).

The objectives of this study were to compare grazing distribution and diet quality of Angus, Brangus, and Brahman cows in extensive pastures in the Chihuahuan Desert. We hypothesized that Brangus cows would travel farther per day and correspondingly use areas farther from water, than Angus and Brahman cows because of the hybrid vigor associated with cross of Brahman (Bos indicus) and the Angus (Bos taurus). We also predicted that Brangus cows would select a higher quality diet than the other two breeds. The comparisons were made during three seasons: 1 ) winter-when the cows were lactating, temperatures were cool, and forage quality was low; 2) early summer-when cows were in early lactation, temperatures were warm, and forage quality was low; and 3) late summerwhen cows were in late lactation, temperatures were warm, and forage quality was good.

\section{METHODS}

\section{Study Site and Animals}

Animal handling and experimental procedures were in accordance with guidelines set by the New Mexico State University's Institutional Animal Care and Use Committee.

This study was conducted at the Chihuahuan Desert Rangeland Research Center (CDRRC) located $37 \mathrm{~km}$ north of Las Cruces in south-central New Mexico (lat $32^{\circ} 32^{\prime} \mathrm{N}$; long $\left.106^{\circ} 48^{\prime} \mathrm{W}\right)$. Soils consist primarily of fine, sandy loams underlain by calcium carbonate hardpans at depths varying from a few centimeters to greater than 1 meter. Based on a 78yr mean, annual precipitation at the CDRRC is $234 \mathrm{~mm}$. Most of the precipitation occurs during the monsoon season of JulySeptember (Fig. 1). Temperatures during the summer are high, with an average maximum temperature of $36^{\circ} \mathrm{C}$ and an average minimum of $16^{\circ} \mathrm{C}$ during June. In January, the average maximum temperature is $13^{\circ} \mathrm{C}$ and minimum is $-3^{\circ} \mathrm{C}$. In 2008, conditions from January to June were dry with approximately $3 \mathrm{~mm}$ of precipitation, whereas the monsoonal period of July through September was relatively wet with 232 mm of precipitation. Rainfall was less than normal during 2009 with $190 \mathrm{~mm}$ of annual precipitation.

Dominant grasses in the study pastures were dropseeds (Sporobolus spp.), threeawns (Aristida spp.), and black grama (Bouteloua eripoda [Torr.] Torr.). Common shrubs were honey mesquite (Prosopis glanulosa Torr.), broom snakeweed ( $\mathrm{Gu}$ tierrezia sarothrae [Pursh] Britton \& Rusby), and creosote bush (Larrea tridentata [Sessé \& Moc. ex DC.] Coville).

Each study pasture contained only one water source (Fig. 2). Forage was readily available during both years of the study, because stocking levels were very light and varied from 242628 ha animal unit month $(\mathrm{AUM})^{-1}$ during each season.

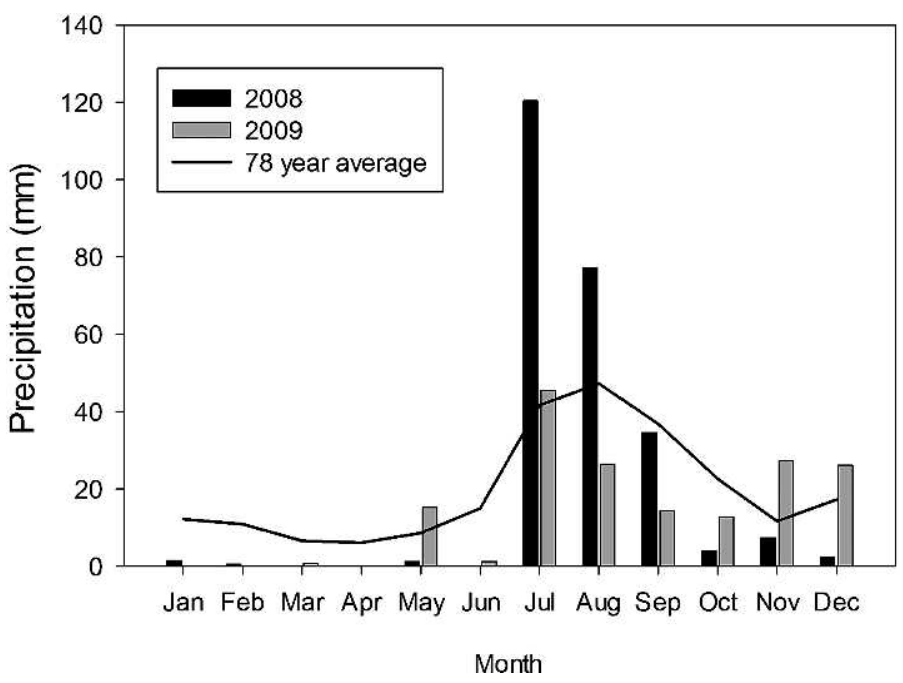

Figure 1. Monthly precipitation at the Chihuahuan Desert Rangeland Research Center for 2008 and 2009 (years of study). Line shows 78-yr average precipitation. 


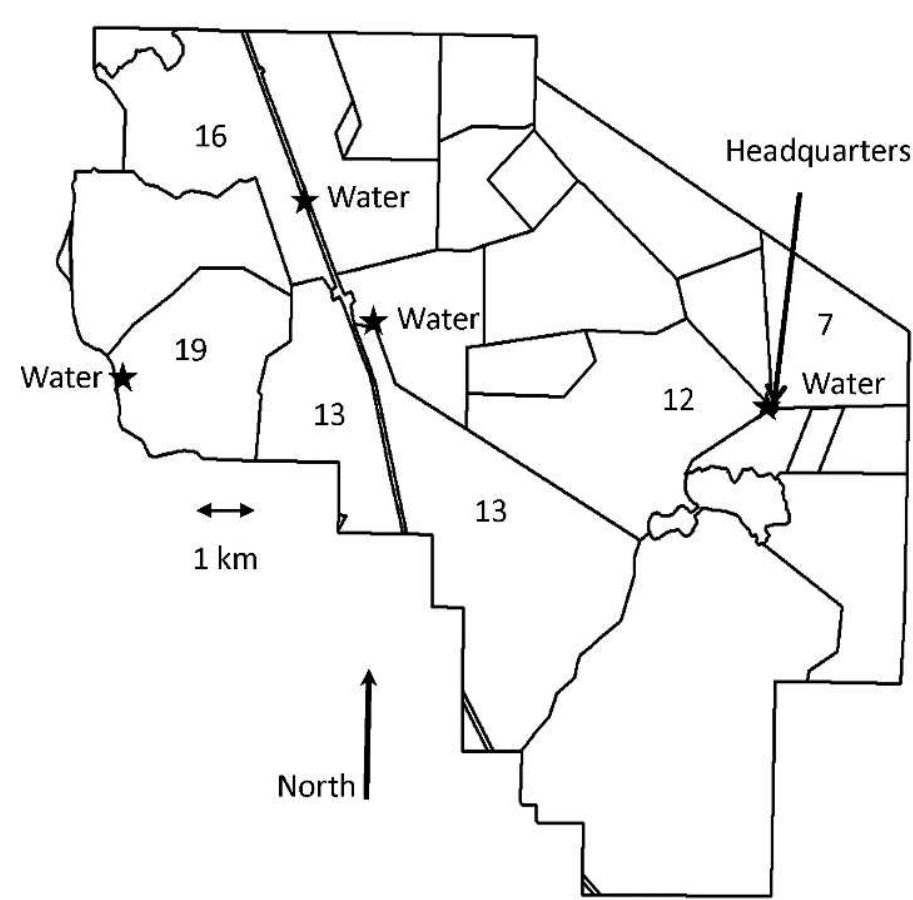

Figure 2. Pasture maps of the Chihuahuan Desert Rangeland Research Center (CDRRC). Study pastures included numbers 12, 13, 16, and 19. Pasture 13 was separated by an interstate highway, but two underpasses allowed cattle to pass freely to both sections. Brahman cows were raised and usually kept in pasture 7 , near headquarters.

During 2008 and the winter of 2009, three pastures (12, 13, and 19) were used (Table 1). However, pasture 16 was utilized during the early summer and late summer of 2009 due to an inadequate supply of water in pasture 19 .

Brahman and Brangus cows were born and raised at the CDRRC. Angus cows were reared on extensive rangelands until 3-4 yr of age at Corona Range and Livestock Research Center (CRLRC) in Corona, New Mexico, and then transported to the CDRRC $1 \mathrm{yr}$ prior to the start of the study and were managed with the CDRRC cattle to become accustomed to the Chihuahuan Desert conditions. Cows calved from late February to late April. The breeding season was from 1 May to 1 August. At the beginning of the study in January 2008, average weights for Angus, Brahman, and Brangus cows were 604 $\mathrm{kg} \pm 14 \mathrm{SE}, 634 \mathrm{~kg} \pm 23 \mathrm{SE}$, and $691 \mathrm{~kg} \pm 13 \mathrm{SE}$, respectively. Body condition scores in January 2008 ( $1=$ emaciated to $9=$ obese) for Angus, Brahman, and Brangus cows were $5.4 \pm 0.1 \mathrm{SE}, 6.0 \pm 0.2 \mathrm{SE}$, and $6.2 \pm 0.1 \mathrm{SE}$, respectively.

\section{Design and Protocol}

2008. Mature (4-10 yr of age) Angus $(n=7)$, Brangus $(n=7)$, and Brahman $(n=7)$ cows were compared and evaluated for 28-32 d during each of three seasons. The first season (winter) began 4 January 2008, prior to calving. The second season (early summer) began 2 May 2008, during early lactation. All cows had calves. The third season (late summer) began 1 August 2008, during late lactation. During each season (winter, early summer, and late summer) of 2008, each breed group of cows was evaluated separately in three study pastures (identified as 12, 13, and 19) for three periods (10- to 14$\mathrm{d} \cdot$ period $^{-1}$ ) in a $3 \times 3$ Latin square design. Pasture and period (first, second, and third) were the blocking factors. Each breed of cows was rotated among the three pastures every 2-wk period to complete the Latin square during each season. Each season consisted of three 2 -wk periods. Due to a limited number of cows in each breed group, about one-half of the cows were used for data collection during multiple seasons within the same year. Global positioning system (GPS) collars were randomly allocated to different cows within each breed group each season. During the early summer season, a bull was placed with each breed group.

2009. The study design during 2009 was implemented in a similar manner to 2008. Breed groups were evaluated during three seasons, consisting of winter, early summer, and late summer, similar to the starting times of 2008. Each season consisted of three 2 -wk periods. Cows were mature (4-10 yr) in age. Within each season, seven cows for each breed group were evaluated. Due to a limited number of cows in each breed group, about one half of the cows were used for data collection during multiple seasons. Breed groups were combined and evaluated in same pasture at the same time. All 21 cows were rotated together among pastures 12, 13, and 19 during the winter season. Pasture 16 replaced pasture 19 during the early and late summer seasons. The sequence of pasture rotation was randomly selected. A bull was placed with the cows during the early summer season. All cows had calves in the early and late summer seasons.

Fall 2008. A separate substudy involving only Brahman cows was conducted during the fall of 2008 to evaluate the unexpected grazing patterns observed during the previous winter, early-summer, and late-summer seasons of 2008. Brahman cows at the CDRRC were born and raised together and usually grazed in the same pasture (pasture 7). Herd mates of the study cows remained at headquarters in pasture 7 while study cows grazed pastures 12, 13, and 19 during the winter, early-summer, and late-summer seasons. In a separate study

Table 1. General terrain attributes of study pastures used in 2008 and 2009.

\begin{tabular}{lccrr}
\hline & \multicolumn{3}{c}{ Pasture } \\
\cline { 2 - 5 } \multicolumn{1}{c}{ Attribute } & 12 & 13 & 19 & 1450 \\
\hline Size (ha) & 1960 & 3770 & 1490 \\
Slope (\%) & $1-16$ & $1-10$ & $1-28$ & $1-12$ \\
Elevation (m) & $1100-1300$ & $1100-1350$ & $1200-1800$ & 8.9 \\
Max. distance to water (km) & 7.9 & 10.2 & 9.2 & steep, rocky \\
Terrain & gentle, bajada & gentle, arroyos & gentle, bajada \\
\hline
\end{tabular}


during fall 2008, all Brahman cows were combined $(n=20)$ at the CDRRC, and their distribution patterns evaluated in pastures 13 and 19 to determine if social interactions might have affected behavior of the Brahman breed group during the winter, early-summer, and late-summer seasons. This study began in December 2008 (after weaning) and consisted of two periods $\left(14-d \cdot\right.$ period $\left.^{-1}\right)$. In the first period, cows were in pasture 19 and during the second period cows were in pasture 13.

\section{GPS Tracking}

For both 2008 and 2009, two randomly selected cows from each breed were tracked with Lotek GPS 3300 collars (Lotek Wireless, Newmarket, Ontario, Canada). GPS collars were randomly assigned to cows at the beginning of each season for each study year. Cow positions were recorded at 10-min intervals, equivalent to 144 positions per 24 -hr period, except during the winter of 2009 when cows were tracked at 15 -min intervals. For the fall 2008 study (Brahman cows only), 6 of the 20 cows (randomly selected) were tracked at 10-min intervals.

Activity sensors on the Lotek collars recorded the number of movements that the collar made in two directions (left and right, and fore and aft). Sensors recorded movements for $4 \mathrm{~min}$ during every 5 -min period (default setting). Counts for each sensor during the periods between fixes were averaged.

Distance to water was calculated for each recorded position and averaged for each cow during each period of each season. Distance traveled per day was determined by summing the successive distances between recorded positions of each collared cow and dividing by the number of days the cows were tracked in a pasture. Stationary cattle appear to move because of GPS error, causing distance traveled to be overestimated by 15\% (Ganskopp and Johnson 2007). Therefore, distance traveled per day $\left(\mathrm{km} \cdot \mathrm{d}^{-1}\right)$ and average distance to water $(\mathrm{m})$ also were evaluated using only positions recorded when cows were active and not resting. Positions recorded from GPS collars were classified as resting (not active) if both of the following criteria were met: i) the distance between two successive GPS locations was less than $20 \mathrm{~m}$; and ii) the left-right and fore-aft sensor counts were less than 50 . Similar to Ganskopp and Johnson (2007), the criteria were based on the inflection point of cumulative values of observed resting behavior during a separate study at the CDRRC (Russell 2010). These criteria predicted observed resting and active behavior with an accuracy over $90 \%$.

To evaluate terrain use, slope, elevation, and distance to water were determined for each position using a digital elevation model of the study pastures (US Geological Service, Reston, VA) and ArcView 3.3 geographical information software (ESRI, Redlands, CA). Terrain attributes of each position recorded for each cow in each pasture during a season were averaged. Other variables analyzed from the GPS collar data were time spent at water and daily number of trips to water. If a cow's location was within $200 \mathrm{~m}$ of a water source, the animal was considered at water. A trip to water was defined as a cow being within $200 \mathrm{~m}$ of a water source for longer than 20 consecutive min.

Tortuosity of animal movement patterns was evaluated using fractal, sinuosity, and efficiency of orientation and movement analyses (Benhamou 2004). Fractal dimension, sinuosity, and orientation efficiency of grazing pathways were calculated for all seasons in both years except for the winter season of 2009 because the GPS fix interval was 15 rather than $10 \mathrm{~min}$. The longer time between positions was considered too coarse for analyses of movement path tortuosity. Previous studies have shown that in heterogeneous environments, areas of concentrated search are typically characterized by low speed and high sinuosity (Ward and Saltz 1994; Fortin 2003). Furthermore, fractals can reveal breed differences more effectively than other measures of path tortuosity because effects of scale are incorporated, which allows comparisons among animals with different diets, physiology, body size, or vagility (Benhamou 2004). In order to determine the tortuosity of distinct foraging bouts, grazing pathways between periods of resting were evaluated. Only consecutive positions classified as active were used in the pathway analyses. Criteria and established thresholds used to classify active and resting behavior for distance traveled per day were used in the assessment of grazing pathway tortuosity. In addition, GPS locations that were recorded within $200 \mathrm{~m}$ of water were excluded from pathway analyses.

Fractal dimension provided a measure of the path tortuosity with a value of 1 , characterizing linear movement and a value of 2, characteristic of Brownian movement. Brownian movement suggested that a path visited all points in a portion of two-dimensional space, leaving no areas unfilled and that the path was very convoluted (Mandelbrot 1983; Turchin 1996). Orientation efficiency is a ratio between the magnitude of the movement component in the goal direction and the magnitude of movement actually performed (Bovet and Benhamou 1991; Turchin 1996; Benhamou 2004). In this study, orientation efficiency was calculated as the distance between the initial and ending position of an active bout divided by the total distance traveled during the corresponding active bout. Lengths of pathways were derived using the Pythagorean Theorem on Universal Transverse Mercator (UTM) coordinates. A very straight path suggested oriented movement, but a highly sinuous search correspondingly resulted in a more tortuous path with low orientation efficiency (Turchin 1991). Benhamou (2004) concluded that this ratio constituted a reliable estimator of the orientation efficiency of a path oriented towards an infinitely distant goal. Turning angles and step lengths of pathways have no meaning when analyzed separately (Benhamou 2004). However, combining the two measures defined a sinuosity index of pathways (Benhamou 2004). Sinuosity was considered to be a reliable index of tortuosity because it involved all angles of the path length and was based on entire path structure. Sinuosity also can be more reliable than orientation efficiency, because accuracy of sinuosity estimates increase with the path length or the sampling frequency, whereas orientation efficiency only considers the relative locations of the first and last points of the path (Benhamou 2004). Fractal dimension and sinuosity measures were determined using Hawth's Tools in Arcmap 9.1 (ESRI).

\section{Diet Quality Estimation}

Fecal samples were collected from each cow at the end of each period during 2008. Fecal samples were frozen, and later dried 
for $48 \mathrm{~h}$ at $50^{\circ} \mathrm{C}$ and ground in a Wiley mill to pass a $1-\mathrm{mm}$ screen. Fecal samples were scanned using a scanning reflectance monochromator (Model 6500, NIR Systems Inc., Silver Springs, MD). Reflected energy (log [1/R], where $\mathrm{R}=$ reflectance) was measured and averaged over 32 scans and recorded at 2-nm intervals from 1100 to $2500 \mathrm{~nm}$ (ISI 1999). Diet crude protein (CP) and digestible organic matter (DOM) of cows during each period and season were estimated using equations originally developed by Lyons and Stuth (1992), and updated by the Texas A\&M Grazing Animal Nutrition Lab (Temple, TX).

\section{Statistical Analyses}

For the studies conducted in 2008, each season (winter, early summer, and late summer) was analyzed separately. Data were analyzed as a $3 \times 3$ Latin square design using the MIXED procedure of SAS (SAS Institute, Inc., Cary, NC). The model included breed, pasture, and period as fixed effects, and the pasture $\times$ period $\times$ breed interaction was included as a random effect and used as the error term. The experimental unit was the combination of breed and pasture and/or period $(n=9)$. Tracking data from individual collared cows and fecal NIRS from individual cows were subsamples. Mean separation among breeds was completed using the pdiff option of the LS MEANS statement (SAS Institute, Inc.).

For the studies conducted in 2009, data were analyzed as a completely randomized block design using the MIXED procedure of SAS (SAS Institute, Inc.). The model included breed and pasture as fixed effects. Pasture was the blocking factor. The breed $\times$ pasture interaction was included as a random effect and used as the error term. The experimental unit was the combination of breed and pasture $(n=9)$. Tracking data from individual collared cows and fecal NIRS from individual cows were subsamples. Each season (winter, early summer, and late summer) was analyzed separately. Mean separation among breeds was completed using the pdiff option of PROC MIXED (SAS Institute, Inc.).

For the supplementary trial conducted during the fall of 2008 using only Brahman cattle, data were analyzed as a completely randomized block design using the MIXED procedure of SAS (SAS Institute, Inc.). Average distance to water and distance traveled values during the fall were compared to previous seasons for Brahman cows only. Model included pasture, season, and period as fixed effects, and the pasture $\times$ period interaction within season was a random effect and served as the error term.

Because there were only nine experimental units in all analyses but the fall 2008 study, and to make the discussion of experimental results more concise, breed group means are described as different if $P \leq 0.10$. $P$ values are provided so the reader can make their own determination of statistical significance. Means are reported \pm 1 SE throughout.

\section{RESULTS}

\section{Terrain Use}

No differences in the slope of Angus, Brangus, and Brahman cow locations were detected during the winter $(P=0.24)$, early summer $(P=0.28)$, and late summer $(P=0.40)$ of 2008 . The average slope of cow positions during the winter, early summer, and late summer was $8.1 \% \pm 0.3,5.8 \% \pm 0.2$, and $6.7 \% \pm 0.3$, respectively. All breed groups in 2008 used steeper $(P<0.10)$ slopes in pasture 19 than in pastures 12 and 13 . Pasture 19 contained the most vertically challenging terrain of the study pastures with slopes of up to $28 \%$. No differences in average elevation of recorded locations were detected $(P>0.10)$ among breed groups in all three seasons during 2008. Average elevation during the winter, early summer, and late summer seasons was $1303 \mathrm{~m} \pm 7,1316 \mathrm{~m} \pm 5$, and 1322 $\mathrm{m} \pm 5$, respectively.

No differences in the slope of Angus, Brangus, and Brahman cow locations were detected $(P \geq 0.10)$ during all three seasons in 2009. Average slope of cow locations was $9.2 \% \pm 1.2$, $3.1 \% \pm 0.1$, and $3.1 \% \pm 0.2$ for the winter, early summer, and late summer seasons, respectively. No differences among breed groups for the elevation of recorded positions were detected $(P>0.10)$ during the 2009 winter $(P=0.41 ; 1311 \mathrm{~m} \pm 6)$ and early summer $(P=0.56 ; 1322 \mathrm{~m} \pm 1)$ seasons. However, Angus cows (1324 $\mathrm{m} \pm 1)$ used higher elevations $(P=0.06)$ than Brangus (1320 $\mathrm{m} \pm 1$ ) and Brahman cows (1321 $\mathrm{m} \pm 1)$ during late summer.

\section{Distance Traveled}

Brahman cows traveled greater $(P=0.06$; Table 2$)$ distances per day during the 2008 winter season than Angus or Brangus cows. However, no differences in distance traveled per day were detected among breed groups during early $(P=0.15)$ and late summer $(P=0.15)$ seasons in 2008 . For the analyses of the fall 2008 substudy, no differences in the distance traveled per day by Brahman cows were detected ( $P=0.39$; Table 2$)$ among the winter, early summer, late summer, and fall seasons. On average, Brahman cows traveled $10.4 \mathrm{~km} \cdot \mathrm{d}^{-1} \pm 0.9$ when all CDRRC Brahman cows grazed together in the same pasture. In contrast to the winter of 2008 , no differences $(P=0.12$; Table 2) among Angus, Brangus, and Brahman cows for daily distance traveled were detected during the winter of 2009. Brahman cows, however, traveled greater distances per day during the early and late summer seasons of $2009(P \leq 0.01)$ than Angus or Brangus cows.

Distance traveled was also assessed by analyzing GPS fixes recorded when cows were active and not resting. When cows were active, Brahman cows traveled greater distances per day $(P<0.05$; Table 2$)$ than Angus or Brangus cows during all three seasons in 2008. No differences among breed groups were detected $(P>0.10)$ in proportion of time spent resting, and all breeds were active $45-56 \%$ of the time. Similar to results of 2008 with resting periods excluded, Brahman cows traveled greater distances per day during all three seasons $(P \leq 0.10$; Table 2) in 2009 than Angus or Brangus cows.

\section{Average Distance to Water}

No differences were detected among breed groups in their average distance to water $(P>0.10$; Table 3$)$ during the winter, early summer, and late summer seasons in 2008. All breed groups were approximately $1.6 \mathrm{~km}$ from water when averaged over the course of each season during 2008. For the fall 2008 
Table 2. Least square means and standard errors (SE) of distance traveled per day during three seasons in 2008 and 2009 by Angus, Brangus, and Brahman mature cows in the Chihuahuan Desert $(n=9)$.

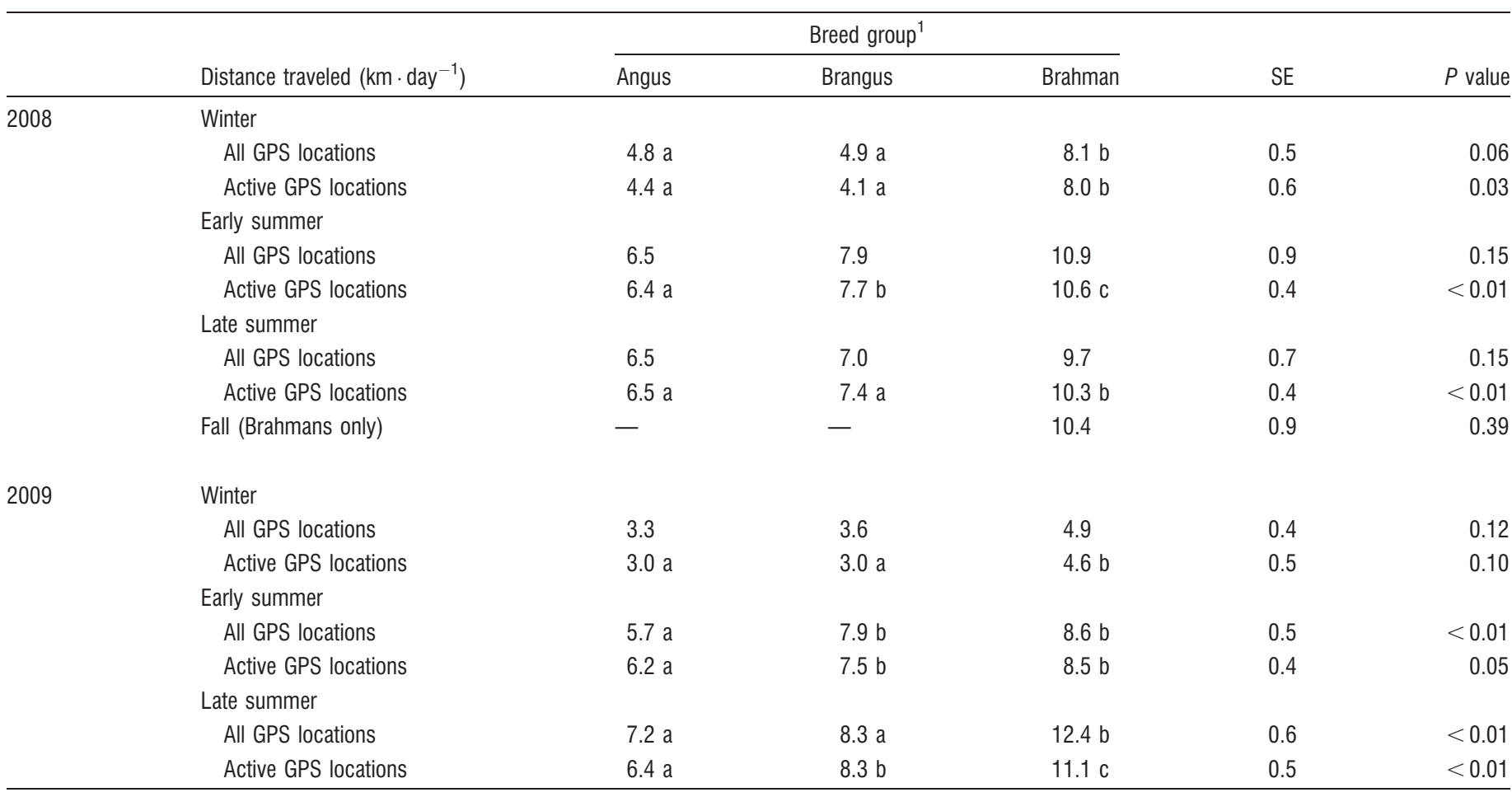

${ }^{1}$ Least square means within the same row with different superscripts differ $(P<0.10)$.

substudy analyses using only Brahman data, cows were closer $(P=0.06$; Table 3$)$ to water during the fall and winter seasons than during the spring and summer seasons. Similar to 2008, no difference among breed groups in their average distance to water was detected $(P>0.10$; Table 4$)$ during winter, early summer, and late summer seasons in 2009.
Distance to water was also assessed by analyzing GPS fixes recorded when cows were active and not resting. Here too, no differences in breed groups $(P \geq 0.10$; Table 3$)$ were detected for average distance to water during all three seasons in 2008. Likewise, no differences among Angus, Brangus, and Brahman cows were detected $(P \geq 0.10$; Table 4$)$ for average distance to

Table 3. Least square means and standard errors (SE) of distance to water, time spent at water and daily number of trips to water during three seasons in 2008 by Angus, Brangus, and Brahman mature cows in the Chihuahuan Desert $(n=9)$.

\begin{tabular}{|c|c|c|c|c|c|}
\hline \multirow[b]{2}{*}{ Measurement } & \multicolumn{3}{|c|}{ Breed group } & \multirow[b]{2}{*}{ SE } & \multirow[b]{2}{*}{$P$ value } \\
\hline & Angus & Brangus & Brahman & & \\
\hline \multicolumn{6}{|l|}{ Winter } \\
\hline Average distance to water (all locations; m) & 1049 & 746 & 1308 & 473 & 0.74 \\
\hline Average distance to water (active data; m) & 1047 & 784 & 1367 & 193 & 0.25 \\
\hline Time spent at water (\%) & 25.1 & 20.7 & 23.3 & 7.3 & 0.92 \\
\hline Trips to water (trips . day ${ }^{-1}$ ) & 1.07 & 1.06 & 1.02 & 0.21 & 0.53 \\
\hline \multicolumn{6}{|l|}{ Early summer } \\
\hline Average distance to water (all locations; m) & 1375 & 1542 & 1676 & 450 & 0.90 \\
\hline Average distance to water (active data; m) & 1365 & 1472 & 1680 & 153 & 0.41 \\
\hline Time spent at water (\%) & 31.2 & 17.6 & 29.7 & 10.1 & 0.65 \\
\hline Trips to water (trips $\cdot$ day $^{-1}$ ) & 1.85 & 1.33 & 2.09 & 0.50 & 0.62 \\
\hline \multicolumn{6}{|l|}{ Late summer } \\
\hline Average distance to water (all locations; m) & 1454 & 1148 & 1692 & 175 & 0.30 \\
\hline Average distance to water (active data; m) & 1393 & 1303 & 1463 & 136 & 0.54 \\
\hline Time spent at water (\%) & 16.7 & 14.9 & 21.7 & 4.8 & 0.65 \\
\hline Trips to water (trips $\cdot$ day $^{-1}$ ) & 0.83 & 1.15 & 1.43 & 0.37 & 0.48 \\
\hline \multicolumn{6}{|l|}{ Fall (Brahmans only) } \\
\hline Average distance to water $(\mathrm{m})$ & - & - & 1607 & 23 & \\
\hline
\end{tabular}


Table 4. Least square means and standard errors (SE) of distance to water, time spent at water, and daily number of trips to water during three seasons in 2009 by Angus, Brangus, and Brahman mature cows in the Chihuahuan Desert $(n=9)$.

\begin{tabular}{|c|c|c|c|c|c|}
\hline \multirow[b]{2}{*}{ Measurement } & \multicolumn{3}{|c|}{ Breed group $^{1}$} & \multirow[b]{2}{*}{ SE } & \multirow[b]{2}{*}{$P$ value } \\
\hline & Angus & Brangus & Brahman & & \\
\hline \multicolumn{6}{|l|}{ Winter } \\
\hline Average distance to water (all locations; m) & 698 & 1090 & 1257 & 283 & 0.44 \\
\hline Average distance to water (active data; m) & 659 & 1063 & 1231 & 258 & 0.28 \\
\hline Time spent at water $(\%)$ & 20.4 & 20.2 & 17.7 & 3.9 & 0.87 \\
\hline Trips to water (trips · day ${ }^{-1}$ ) & 1.03 & 0.94 & 1.11 & 0.13 & 0.67 \\
\hline \multicolumn{6}{|l|}{ Early summer } \\
\hline Average distance to water (all locations; m) & 1185 & 1029 & 964 & 69 & 0.13 \\
\hline Average distance to water (active data; m) & $1274 \mathrm{a}$ & $1072 \mathrm{a}$ & $995 \mathrm{~b}$ & 61 & 0.05 \\
\hline Time spent at water (\%) & 24.9 & 26.6 & 29.3 & 2.8 & 0.55 \\
\hline Trips to water (trips $\cdot$ day $^{-1}$ ) & 4.22 & 1.30 & 1.28 & 2.50 & 0.51 \\
\hline \multicolumn{6}{|l|}{ Late summer } \\
\hline Average distance to water (all locations; m) & 1276 & 1364 & 1337 & 164 & 0.93 \\
\hline Average distance to water (active data; m) & 1298 & 1545 & 1368 & 90 & 0.18 \\
\hline Time spent at water (\%) & 15.9 & 23.1 & 18.4 & 3.8 & 0.47 \\
\hline Trips to water (trips $\cdot$ day $^{-1}$ ) & $1.15 \mathrm{a}$ & $1.36 \mathrm{a}$ & $1.81 \mathrm{~b}$ & 0.10 & 0.03 \\
\hline
\end{tabular}

${ }^{1}$ Least square means within the same row with different superscripts differ $(P<0.10)$.

water during the winter and late summer seasons in 2009. However, Angus cows used areas farther $(P=0.05)$ from water than Brangus or Brahman cows during early summer 2009.

\section{Behavior near Water}

No differences among breed groups were detected for time spent at water $(P>0.10$; Table 3$)$ during the winter, early summer, and late summer seasons in 2008. Likewise, no differences among Angus, Brangus, and Brahman cows were detected $(P>0.10$; Table 4$)$ for time spent at water during all seasons in 2009. No differences among Angus, Brangus, and Brahman cows were detected for the daily number of trips to water $(P>0.10$; Table 3$)$ during winter and early and late summer seasons of 2008. Similar to 2008, no differences $(P>0.10$; Table 4) in Angus, Brangus, and Brahman cows were detected in the daily number of trips to water during the winter and early summer seasons in 2009. However, during late summer season in 2009, Brahman cows made more $(P=0.03$; Table 3) daily trips to water than Angus and Brangus cows.

\section{Tortuosity of Grazing Pathways}

No differences in Angus, Brangus, and Brahman cows were detected $(P>0.10)$ with respect to fractal dimension in 2008 during all study seasons. Fractal dimensions of grazing pathways averaged $1.43 \pm 0.10,1.37 \pm 0.05$, and $1.55 \pm 0.09$ during the 2008 winter, early summer, and late summer seasons, respectively. No differences among breed groups were detected $(P>0.10$; Table 5$)$ in grazing pathways during the 2009 early and late summer seasons in respect to fractal dimension. Fractal dimensions were not evaluated during the winter of 2009.

No differences among Angus, Brangus, and Brahman cows were detected $(P>0.10)$ in the sinuosity of grazing pathways during any season in 2008. Sinuousity of grazing pathways averaged $3.34 \pm 0.59,5.42 \pm 0.90$, and $3.34 \pm 0.48$ during the 2008 winter, early summer, and late summer seasons, respectively. During 2009 early summer and late summer seasons, Brahman cows displayed more sinuous pathways $(P \leq 0.10$; Table 5) than Angus cows. Sinuosity was not evaluated during the winter of 2009.

Table 5. Least square means and standard errors (SE) of fractal dimension, sinuosity, and orientation efficiency estimates during two seasons in 2009 by Angus, Brangus, and Brahman mature cows in the Chihuahuan Desert $(n=9)$.

\begin{tabular}{|c|c|c|c|c|c|}
\hline \multirow[b]{2}{*}{ Measurement } & \multicolumn{3}{|c|}{ Breed group $^{1}$} & \multirow[b]{2}{*}{ SE } & \multirow[b]{2}{*}{$P$ value } \\
\hline & Angus & Brangus & Brahman & & \\
\hline \multicolumn{6}{|l|}{ Early summer } \\
\hline Fractal dimension & 1.43 & 1.49 & 1.67 & 0.15 & 0.58 \\
\hline Sinuosity & $2.83 \mathrm{a}$ & $3.54 a b$ & $4.67 \mathrm{~b}$ & 0.42 & 0.08 \\
\hline Orientation efficiency (\%) & $58.5 \mathrm{a}$ & $47.8 \mathrm{~b}$ & $40.9 \mathrm{c}$ & 2.3 & 0.01 \\
\hline \multicolumn{6}{|l|}{ Late summer } \\
\hline Fractal dimension & 1.58 & 1.72 & 1.91 & 0.11 & 0.13 \\
\hline Sinuosity & $2.68 \mathrm{a}$ & $3.88 \mathrm{~b}$ & $4.07 \mathrm{~b}$ & 0.32 & 0.07 \\
\hline Orientation efficiency (\%) & $53.3 \mathrm{a}$ & $48.6 \mathrm{a}$ & $40.5 \mathrm{~b}$ & 2.5 & 0.05 \\
\hline
\end{tabular}

${ }^{1}$ Least square means within the same row with different superscripts differ $(P<0.10)$. 


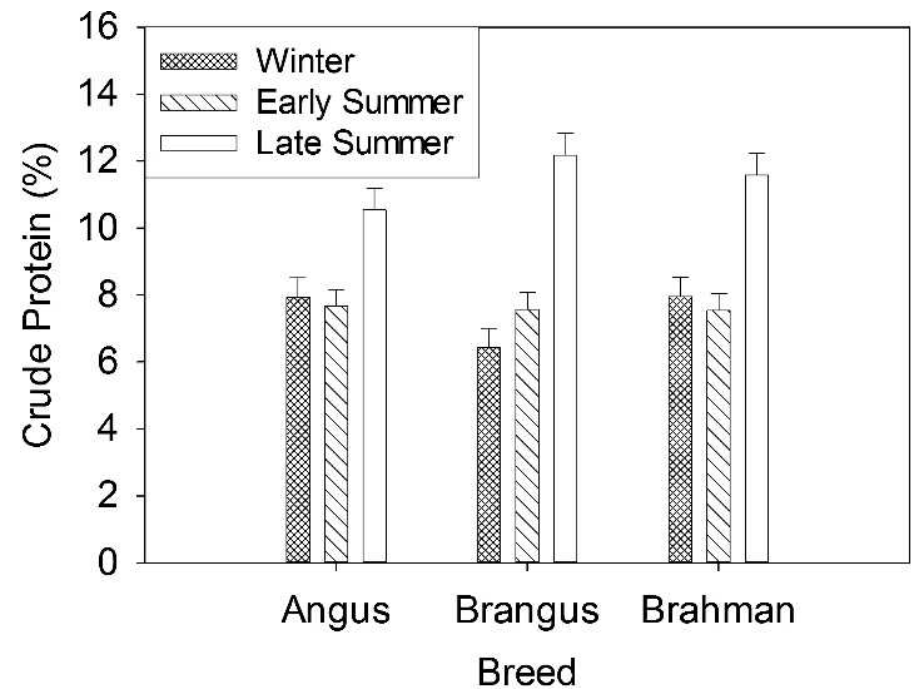

Figure 3. Least square means of Angus, Brangus, and Brahman diets for crude protein during the winter, early summer, and late summer seasons of 2008. Bars represent pooled standard errors.

No differences among Angus, Brangus, and Brahman cows were demonstrated $(P>0.10$; Table 5$)$ in the orientation efficiency of grazing pathways during the winter and late summer seasons in 2008. Orientation efficiency averaged $44.9 \% \pm 3.0$ and $48.2 \% \pm 4.7$ for the winter and later summer seasons, respectively. Pathways of Angus $(60.5 \% \pm 4.6)$ cows were more linear $(P=0.09)$ than those of Brahman $(30.8 \% \pm 4.6)$ or Brangus $(39.4 \% \pm 4.6)$ cows during 2008 early summer season.

Similar to our findings regarding orientation efficiency during the early summer season of 2008, pathways of Angus cows were more linear $(P<0.10$; Table 5$)$ than Brahmans during the 2009 early season, and Brangus cows were intermediate. In late summer, pathways of Angus and Brangus cows were more linear $(P<0.10)$ than Brahmans. Orientation efficiency was not evaluated during the winter of 2009.

\section{Diet Quality}

In 2008, no differences in $\mathrm{CP}$ of diets were detected $(P>0.10)$ among Angus, Brangus, and Brahman cows during the winter, early summer, and late summer seasons based on fecal NIRS (Fig. 3). No differences in DOM $(P>0.10)$, fecal nitrogen $(P>0.10)$, or fecal phosphorus $(P>0.10)$ were detected among breed groups during any of the three seasons. Diet quality consistently increased for all breed groups during the late summer of 2008. This increase in overall diet quality was most likely due to the monsoon season precipitation (Fig. 1). Average precipitation during July-September 2008 was approximately $232 \mathrm{~mm}$ compared to $3 \mathrm{~mm}$ of winter and spring precipitation during January-June 2008.

\section{DISCUSSION}

\section{Terrain Use}

Overall, virtually no differences in slope or elevation use were detected among breed groups, both in 2008 when they were separated and in 2009 when they grazed the same pasture. In contrast, Bailey et al. (2001) and VanWagoner et al. (2006) found that breeds originating in mountainous terrain, such as Tarentaise and Piedmontese, tended to use more rugged terrain than breeds developed in more gentle terrain, such as Hereford and Angus. In this study, Angus, Brahman, and the composite Brangus breed groups originated in areas of relatively gentle terrain.

Anecdotal observations suggest that Brahman cows might have avoided steep and rugged slopes because they traveled the length of pasture 19 to the exit gate (about $8 \mathrm{~km}$ from water) on a daily basis, rather than grazing slopes which Angus and Brangus cows regularly used. At the end of each 2-wk period, the exit gate of pasture 19 was left open in the afternoon and the Brahman cows always exited the pasture through that gate by the following morning. Angus and Brangus cows, however, had to be herded out of the rugged terrain in pasture 19 by horseback riders at the end of the same time frame.

\section{Distance Traveled}

Estimates of distance traveled based on all GPS fixes were probably less precise and less accurate than those based solely on fixes obtained when cows were active. Standard errors associated with the former type of estimate were usually greater than those associated with the latter. Based on the more conservative method of estimation, and contrary to our hypothesis, it was Brahman rather than Brangus cows that traveled the greatest distances per day during all seasons in both study years. Unlike the Herbel and Nelson (1966) study where the Brahman-British crossbreed (Santa Gertrudis) walked farther per day than the British breed (Hereford), the Brahman-British cross (Brangus) did not walk farther than the British breed (Angus) in this study.

The consistent differences found among breeds in daily distance traveled during the spring and summer months might partially be attributed to heat tolerance in Bos indicus cattle. Maximum temperatures during June, July, and August can range from $33-40^{\circ} \mathrm{C}$. Bos indicus breeds and their crosses have better heat regulatory capacities than Bos taurus breeds, and the latter have a higher heat loading at the skin and must evaporate substantially more sweat than Bos indicus to maintain normal body temperatures (Blackshaw and Blackshaw 1994). Respiration rate in Brahman cows are characteristically lower than in Bos taurus breeds, regardless of ambient temperature (Hammond and Olson 1994). These physiological differences between Bos taurus and Bos indicus cattle might partially explain the ability to travel greater distances per day.

The willingness of Brahman cows to travel was especially apparent in pasture 19 where they walked over $8 \mathrm{~km}$ from water near the western boundary to the northeast gate on a daily basis. Social factors were initially thought to be at play, because all Brahman cattle at the CDRRC normally are kept near headquarters in pasture 7 , northeast from pasture 12 (Fig. 2). The consistent movement of cows from water at the western boundary to the gate in the northeast corner of the pasture was thought to be an attempt to return to their herdmates. However, Brahman cows exhibited similar grazing patterns after combining all Brahman cows on the CDRRC into pastures 13 and 19 for the substudy during the fall 2008 . 
Brahman cows traveled similar distances per day during the fall as they did during the winter, early summer, and late summer seasons in 2008. Apparently cows were not attempting to return to their herdmates that were kept $13 \mathrm{~km}$ away in pasture 7 near headquarters during the winter, early summer, and late summer seasons. Perhaps Brahman cows preferred grazing in pasture 7 and were attempting to return to that area. Future research should examine the possibility that Brahmans are very gregarious in nature and prefer distinct and familiar home ranges. However, Brahman cows did not display the movement pattern observed in pasture 19 and pasture 13 while grazing in pasture 16, another novel pasture located far from pasture 7. Another possibility is that Brahman cows were not comfortable grazing in areas of rugged terrain. The area grazed in pasture 16 contains gentle terrain and flat areas similar to the terrain used by Brahmans in pasture 7. Pasture 13 and 19 contains more rugged terrain than the other study pastures. Similar terrain types between pasture 7 and 16 might have alleviated the Brahman cows' desire to return to familiar topography.

\section{Average Distance to Water}

The hypothesis that Brangus cows would walk farther and correspondingly use areas farther from water than Angus and Brahman cows was rejected. Contrary to our expectations and predicted response, the breed that traveled the farthest per day did not correspondingly graze greater distances from water. Although Brahman cows traveled greater distances per day during most of the study, there were no differences among breed groups in their average distance to water during 2008 and 2009 if all GPS fixes were evaluated. Using active data, Brahman cows were closer to water than the other breed groups during early summer 2009. Breed groups used the same areas of study pastures, except in pasture 19 where Brahmans spent a great deal of time in the gentler slopes of the east side of the pasture near their normal grazing area. Although no consistent differences among breed groups were observed in this study, Bailey et al. (2001) reported Hereford $\times$ Tarentaise cows used areas horizontally farther from water than Hereford cows. Similarly, VanWagoner et al. (2006) also reported cows from Tarentaise dams traveled farther horizontally from water than cows from Hereford x Tarentaise cross dams. Angus-sired cows were observed closer to water than Charolais- or Piedmontese-sired cows.

\section{Time Spent at Water}

Some difference among breed groups was expected for time spent at water during the warmer weather of the early and late summer seasons. Bos indicus and Bos taurus cattle drink similar amounts of water at cooler temperatures $\left(<15^{\circ} \mathrm{C}\right)$; however, at higher temperatures $\left(>35^{\circ} \mathrm{C}\right)$ water intake of Bos indicus cattle can be $60 \%$ or less than that of Bos taurus (Winchester and Morris 1956). However, no differences were observed during both years, and no clear pattern of time spent at water evolved on a season-by-season basis. Herbel and Nelson (1966) observed seasonal activities of Santa Gertrudis and Herford cattle and also found no difference in time spent watering between these breeds during the fall, winter, spring, and summer.
Brahman cows walked greater distances per day than Angus or Brangus cattle; however, Brahmans did not graze areas farther from water. A possible reason for Brahman cows walking farther than the other breed groups was that they returned to water more frequently. However, no differences in the daily number of trips to water were detected among breed groups during the majority of the study. This was unexpected because Brahman cows are adapted to high temperatures (Webster 1991). In addition, long-term, desert-adapted Brangus cows spent a smaller percentage of time at water and longer bouts away from water when compared to Brangus cows that did not graze continuously in the Chihuahuan Desert (Bailey et al. 2010). Previous experience might allow desert-adapted cattle to forage more efficiently and respond to adverse climatic conditions and other challenges that are typical of the Chihuahuan Desert (Bailey et al. 2010). In this study, all cows had spent at least $1 \mathrm{yr}$ in the Chihuahuan Desert. The site in central New Mexico where the Angus cows were raised consists of extensive rangeland pastures and semiarid conditions.

\section{Tortuosity of Grazing Pathways}

Tortuosity of grazing pathways was examined because Brahman cows traveled greater distances per day than Angus or Brangus cows, but did not use areas farther from water. One explanation could be that Brahman cows used a more serpentine route when grazing than other breed groups. However, differences in sinuosity and fractal dimension indices of grazing pathways among breed groups were not detected during any of the three seasons in 2008. Results of the orientation efficiency also did not show consistent differences among breed groups during 2008. In contrast, Brahman cows demonstrated more sinuous pathways than Angus or Brangus cows during both early and late summer seasons of 2009. The differences in responses for Brahman cattle during 2008 and 2009 might partially be the result of the long daily trips from water to the east exit gate in pasture 19, which likely decreased sinuosity and fractal dimension and improved orientation efficiency. In 2009, analyses of tortuosity did not include pasture 19. Overall, these analyses suggested that Brahman cows move differently than Angus or Brangus cows during foraging, and the sinuous path they often take might explain how they can walk farther per day without using areas that are distant from water.

\section{Diet Quality}

The longer distance traveled per day and more tortuous paths of the Brahman cows could possibly be the result of the animals being more selective. Potentially, cattle might move farther and use a more sinuous path in an attempt to locate more nutritious food items. However, we were not able to detect any differences among breed groups in $\mathrm{CP}$ or other indicators of diet quality using fecal NIRS during 2008 (Fig. 3). However, Brahman cows demonstrated more sinuous paths in 2009 than in 2008, but fecal NIRS samples were not evaluated in 2009. Our hypothesis that Brangus cattle would select a higher quality diet was rejected.

Winder et al. (1996) suggested that differences in diet preference might be partially attributed to willingness of some 
breeds to travel farther from water where more palatable forage species are typically more abundant. These researchers found that Brangus consumed more Sporobolus than Angus or Hereford cows and speculated that Brahman-influenced cattle, such as Brangus, might travel farther from water than other breeds and correspondingly might be more likely to consume the Sporobolus found there. In this study, we did not detect any differences among breed groups in their willingness to graze areas far from water, and based on the hypothesis suggested by Winder et al. (1996), no differences in diet selection among breed groups would be expected.

Observed differences in activity, movement patterns, and diet quality of cattle might be a simple function of body mass and associated parameters rather than a breed effect. Cattle breeds typically differ in mature size as well as other characteristics. Correspondingly, it is impossible to completely overcome the potential confounding of body mass when evaluating multiple breeds. In this study, we compare very different breeds (Bos taurus-Angus and Bos indicus-Brahman). Mean body weights of breed groups at the beginning of the study varied by only $87 \mathrm{~kg}$. In two studies with various breeds of Bos taurus cattle (Bailey et al. 2001; VanWagoner et al. 2006), terrain use and distance traveled per day were not related to body weight or body condition. Correspondingly, it is unlikely that differences in movement patterns among breed groups in this study can be entirely explained by variation in body weight.

\section{MANAGEMENT IMPLICATIONS}

Although Brahman cows traveled greater distances per day, that in itself did not increase or improve their ability to graze greater distances from water than Angus or Brangus cows. The ability of Brahman-influenced cattle to withstand high temperatures and harsh desert environments also did not translate into improved grazing distribution in this study. No advantage in grazing distribution was detected for any of the breed groups evaluated (Angus, Brangus, or Brahman), which had prior desert grazing experience. Correspondingly, the decision to use adapted breeds to improve cattle grazing distribution should be based on documented use of rugged terrain or areas far from water rather than the ability to walk long distances. However, with all sampling confined to a relatively small number of animals, application of these results to different populations and environments should be made with some reservation.

\section{ACKNOWLEDGMENTS}

The authors would like to thank Calvin Bailey for his assistance in data collection and cattle management during the study and Dr. Dawn Vanleeuwen for her assistance with the statistical analyses.

\section{LITERATURE CITED}

BAlLEY, D. W. 2004. Management strategies for optimal grazing distribution and use of arid rangelands. Journal of Animal Science 82(E. Suppl.):E147-E153.

Balley, D. W., J. E. Gross, E. A. Laca, L. R. Rittenhouse, M. B. Coughenour, D. M. Swift,
AND P. L. Sims. 1996. Mechanisms that result in large herbivore grazing distribution patterns. Journal of Range Management 49:386-400.

Balley, D. W., D. D. Kress, D. C. Anderson, D. L. Boss, and E. T. Miller. 2001. Relationship between terrain use and performance of beef cows grazing foothill rangeland. Journal of Animal Science 79:1883-1891.

Balley, D. W., M. G. Thomas, J. W. Walker, B. K. Witmore, and D. Tolleson. 2010. Effect of previous experience on grazing patterns and diet selection of Brangus cows in the Chihuahuan Desert. Rangeland Ecology \& Management 63:223-232.

Balley, D. W., AND G. R. Welling. 1999. Modification of cattle grazing distribution with dehydrated molasses supplement. Journal of Range Management 52:575-582.

Bennamou, S. 2004. How to reliably estimate the tortuosity of an animal's path: straightness, sinuosity, or fractal dimension? Journal of Theoretical Biology 229:209-220.

BlackshaW, J. K., and A. W. Blackshaw. 1994. Heat stress in cattle and the effect of shade on production and behaviour: a review. Australian Journal of Experimental Agriculture 34:285-295.

Bovet, P., and S. Benhamou. 1991. Optimal sinuosity in central place foraging movements. Animal Behavior 42:57-62.

FoRTIN, D. 2003. Searching behavior and the value of sampling information by freeranging bison (Bos bison). Behavioral Ecology and Sociobiology 54:194-203.

Franke, D. E. 1980. Breed and heterosis effects of american Zebu cattle. Journal of Animal Science 50:1206-1214.

GansKOPP, D. 2001. Manipulating cattle distribution with salt and water in large aridland pastures: a GPS/GIS assessment. Applied Animal Behaviour Science 73:251-262.

GanskoPP, D. C., AND D. D. JoHnson. 2007. GPS errors in studies addressing animal movements and activities. Rangeland Ecology \& Management 60:350-358.

Hammond, A. C., And T. A. OLson. 1994. Rectal temperature and grazing time in selected beef cattle breeds under tropical summer conditions in subtropical Florida. Tropical Agriculture 71:128-134.

Herbel, C. H., And F. N. Nelson. 1966. Activities of Hereford and Santa Gertrudis cattle on southern New Mexico range. Journal of Range Management 19:173-176.

Hessle, A., M. RutTer, and K. Wallin. 2008. Effect of breed, season and pasture moisture gradient on foraging behavior in cattle on semi-natural grasslands. Applied Animal Behaviour Science 111:108-119.

HoleCHEK, J. L. 1988. An approach for setting the stocking rate. Rangelands 10:1014.

Holechek, J. L., M. G. Thomas, F. Molinar, and D. Galt. 1999. Stocking desert rangelands: what we've learned. Rangelands 21:8-12.

Hooper, J. F., J. P. Workman, J. B. Grumbles, and C. W. Cook. 1969. Improved livestock distribution with fertilizer: a preliminary economic evaluation. Journal of Range Management 22:108-110.

ISI. 1999. WinISI II manual. Port Matilda, PA, USA: Foss NIRSystems Tecator Intrasoft International. $223 \mathrm{p}$.

Lyons, R. K., AND J. W. Stuth. 1992. Fecal NIRS equations for predicting diet quality for free-ranging cattle. Journal of Range Management 45:238-244.

Mandelbrot, B. B. 1983. The fractal geometry of nature. San Francisco, CA, USA: W.H. Freeman. 480 p.

Mclivain, E. H., AND M. C. Shoop. 1971. Shade for improving cattle gains and rangeland use. Journal of Range Management 24:181-184.

RusseLL, M. L. 2010. Grazing distribution and foraging patterns of Angus, Brangus and Brahman cows in extensive rangeland pastures in the Chihuahuan Desert [MS thesis]. Las Cruces, NM, USA: New Mexico State University. 137 p.

TURCHIN, P. 1991. Translating foraging movements in heterogeneous environments into the spatial distribution of foragers. Ecology 72:1253-1266.

TURCHIN, P. 1996. Fractal analyses of animal movement: a critique. Ecology 77:20862090.

Valentine, K. A. 1947. Distance from water as a factor in grazing capacity of rangeland. Journal of Forage 45:749-754.

VanWagoner, H. C., D. W. Balley, D. D. Kress, D. C. Anderson, and K. C. Davis. 2006. Differences among beef sire breeds and relationships between terrain use and performance when daughters graze foothill rangelands as cows. Applied Animal Behaviour Science 97:105-121.

Vermeire, L. T., R. B. Mitchell, S. D. Fuhlendorf, and R. L. Gillen. 2004. Patch burning effects on grazing distribution. Journal of Range Management 57:248-252. 
WaLkER, J. W. 1995. Viewpoint: Grazing management and research now and in the next millennium. Journal of Range Management 48:350-357.

WaRD, D., AND D. Saltz. 1994. Foraging at different spatial scales: Dorcas gazelles foraging for lilies in the Negev desert. Ecology 75:48-58.

WeBSTER, A. J. F. 1991. Metabolic responses of farm animals to high temperature. In: B. Ronchi, A. Nardone, and J. G. Boyazoglu [EDs.]. Animal husbandry in warm climates. Proceedings of the International Symposium on Animal Husbandry in Warm Climates; 25-27 October 1990; Viterbo, Italy. Rome, Italy: European Federation of Animal Science. Energy Metabolism of Farm Animals, EAAP Publication 55. p. 15-22.
Winchester, C. F., And M. J. MorRis. 1956. Water intake rates of cattle. Journal of Animal Science 15:722-740.

Winder, J. A., B. J. Rankin, and C. C. Balley. 1992. Maternal performance of Hereford, Brangus, and reciprocal crossbred cows under semi-desert conditions. Journal of Animal Science 70:1032-1038.

Winder, J. A., D. A. Walker, and C. C. Balley. 1996. Effect of breed on botanical composition of cattle diets on Chihuahuan Desert range. Journal of Range Management 49:209-214.

Workman, J. P., AND J. F. Hooper. 1968. Economic evaluation of cattle distribution practices on mountain rangelands. Journal of Range Management 21:301-304. 